\title{
EFFECT OF DIFFERENT METHODS OF MODIFIED ATMOSPHERE ON KEEPING QUALITY OF EL-AMAR APRICOT FRUITS DURING MARKETING AND COLD STORAGE
}

\author{
EL-ORABY, SAMIA M., AMAL M. HASSAN and OLA M. FEKRY
}

Fruit Handling Res. Dept., Hort. Res. Instit., ARC, Giza, Egypt

(Manuscript received 17 September 2014)

\begin{abstract}
This study was carried out during the two seasons of 2010 and 2011 on El-Amar apricot fruits obtained from Kalubia governorate to compare the effect of some modified atmosphere methods on keeping quality of apricot fruit during marketing and cold storage periods. Fruit moisture loss, firmness, fruit color, respiration rate, physiological disorders and total soluble solids/total acidity ratio were studied during cold storage at $0^{\circ} \mathrm{C}$ $(85-90 \% \mathrm{RH})$ and marketing at room temperature $25-30^{\circ} \mathrm{C}(60-$ $65 \% \mathrm{RH})$. The results showed that the main factors limiting the storage life of El-Amar apricot is fruit moisture loss and physiological disorders (browning pitting and shriveling). The storage life of fruits packed in polyethylene bags was three weeks, fruits coated with coat (1) (gelatin) or coat (2) (gelatin + bees wax and glycerol) had a storage life of two weeks with good fruit quality. Also, control fruits had two weeks storage life but fruit quality was less than other treatments. All treated and untreated fruits had three days marketing period at room temperature but fruit appearance was the best in polyethylene bags.

Key words: apricot, modified atmosphere, polyethylene, coating
\end{abstract}

\section{INTRODUCTION}

Apricot is of paramount importance to both local markets and exportation. It is widely cultivated in Egypt, but has a short harvesting season. Apricot fruits can be used fresh, dried or processed which it is considered as excellent source of vitamins particularly vitamin C, E and also considered as an important source of mineral elements necessary for human nutrition (Sharoba et al., 2007). Apricot is a climacteric fruit with a high metabolic and respiratory rate (Arté, 2002). It is highly sensitive to dehydration since it lacks epidermal waxes that limit the loss of water (Manolopoulou and Mallidis, 1999).

Postharvest changes in fresh fruits cannot be stopped but they can be slowed within certain limits by using various procedures that slow respiration and thus retard ripening such as low temperatures (Mitchell, 1992) and modified atmosphere packaging (Rodriguez-Aguilera and Oliveira, 2009). Also, edible films and coatings can be used to help the fruit preservation because they provide a partial barrier to 
moisture, $\mathrm{O}_{2}$ and $\mathrm{CO}_{2}$ avoiding volatiles loss and even contribute to the production of aroma volatiles (Olivas and Barbosa-Ca' novas, 2005).

Perez et al (2004) found that edible coating can offer a possibility to extend the shelf life of fresh produces by providing a semi permeable coat to gases and water vapor. Also, Infant et al., (2006) indicated that during apricot storage organic acids are the most early oxdisable substrate available for respiration so it is expected that their content declines at postharvest. In addition, Fekry et al., (2008) on peach and Mshraky et al., (2009) on apricot found that fruit weight loss, respiration rate, fruit color and total soluble solids increased gradually throughout the course of the cold storage period, while firmness and total acidity decreased. Elhadidy, (2008) found obviously that coated 'Flame Seedless' grape berries with edible film of gelatin + bees wax and glycerol lower weight loss $\%$ and decay $\%$ while T.S.S/acid ratio and fruit color increased at the end of storage period in comparison with control fruits. In addition, El-Etraby et al., (2009) indicated that (a) red color and (b) yellow color value of Santa Rosa and Golden Japanese plum increased at different storage treatments till the end of cold storage. Fruits treated with ascorbic acid + MAP had the least value. This may be due to that these treatments delay fruit ripening. Lim et al., (2011) cleared that sweet cherry coated with gelatin film had a lower level of moisture loss over the storage period as compared with carboxy methyl cellulose. In addition, Abeer (2011) indicated that modified atmosphere packaging (MAP) by using polyethylene and cold storage for peach and apricot fruits had the lowest weight loss, decay and the highest flesh firmness at the end of cold storage.

"El-Amar" apricot is a local variety, it has high flavor and orange color than other apricot varieties in Egypt (Sharoba et al., 2007). Gentile harvest, handling and use some postharvest supplementary such as low temperature, edible film and packaging material can extent storage life and reduce postharvest losses of apricot fruits (Zarrin Bal et al., 2009).

The aim of this study was to evaluate the impact some methods of modified atmosphere on keeping apricot fruit quality during cold storage and marketing at room temperature.

\section{MATERIALS AND METHODS}

This study was carried out during the two seasons 2010 and 2011 on El-Amar apricot fruits obtained from a private orchard in Kalubia governorate - Egypt. The fruits were gently harvested when the skin ground color turned to yellowish-green, 
whereas, firmness was (17.3-18.2 Ib/inch $\left.{ }^{2}\right)$ and T.S.S /acid ratio (5.8-5.9) (Infante et al., 2006).

Harvested fruits were packed in plastic field boxes and immediately transported to the fruit handling Department, Hort. Res. Inst., Giza.

\section{The selected fruits were divided into four groups:}

1- The first group was packed in sealed polyethylene bags ( $25 \mu \mathrm{m}$ thickness), each bag contains twelve fruits.

2- The second group was coated with gelatin by dipping in gelatin solution $5 \%$ for 5 minutes at $50^{\circ} \mathrm{C}$ (coat1).

3- The third group was coated with edible film contain $5 \mathrm{gm}$ gelatin $+0.1 \mathrm{gm}$ bees wax and $1 \mathrm{~cm}$ of glycerol / liter by dipping for 5 minutes at $50^{\circ} \mathrm{C}$ (coat 2).

4- The fourth group fruits were kept without any coating (control).

All the fruits were packed in carton boxes ( 3 Kilo). Each treatment was represented by six boxes each two acting as a replicate one used for weight loss and decay assessment and the second for quality assessment. All boxes stored at $0^{\circ} \mathrm{C}$ and $85-90 \%$ relative humidity. Three boxes were held at room temperature $25-30^{\circ} \mathrm{C}$ and $60-65 \%$ relative humidity. Fruits were examined every week for cold storage and at the end of room temperature 4 days for physical and chemical properties.

\section{Fruit physical analysis :}

1- Fruit moisture loss \%: The fresh weight of fruits was periodically weighted and the percentage of weight loss was calculated by the difference between the initial weight and that was recorded at the date of sampling.

2- Fruit color: It was quantified at tristimualus colorimeter data using Hunter colorimeter model DP9000 (a\&b) (a) (green-red) (b) (blue-yellow) values were determined MC-Giuire, (1992).

3- Fruit Firmness (Ib / inch ${ }^{2}$ ): It was determined by Magnes and Taylar pressure tester using apparatus $5 / 16$ plunger.

4- Respiration rate: It was determined according to Cross method (1966). The respiration rate was calculated as $\mathrm{ml} \mathrm{CO}_{2} / \mathrm{kg} / \mathrm{hr}$ as follows:

Respiration rate $=\underline{(\Delta \% \times 10) \text { (Free space volume of container in } \mathrm{ml})}$

(Product F. wt. in $\mathrm{kg}$ ) (Time container enclosed in hour)

5- Physiological disorder percentage: Physiological disorder percentage of apricot fruits were estimated at the end of storage on total fruit number.

\section{Fruit chemical analysis :}

1- Total soluble solid percentage: Abbé refrectometer was used to determine the percentage of total soluble solids in fruit juice (A.O.A.C. 1990). 
2- Titratable acidity percentage: It was determined as malic acid according to (A.O.A.C. 1990).

3- T.S.S/acid ratio was calculated.

\section{Statistical analysis:}

The completely randomized design was adopted for this investigation. The obtained data were statically analyzed according to Snedecor and Cochran (1990). Averages were compared using the L.S.D. values at $5 \%$ level.

\section{RESULTS AND DISCUSSION}

\section{Fruit moisture loss percentage:-}

Data presented in tables ( 1 and 5 ) indicated that fruit moisture loss percentage was increased gradually and significantly after one week of storage and with prolonging the period of storage in both seasons of storage.

Fruit moisture loss was significantly reduced by all treatments compared with control. Fruits packed in polyethylene had utmost significantly effect on fruit moisture loss $(0.26,0.28 \%)$ followed by fruits treated with coat $(2)(10.88,11.59 \%)$ and coat (1) $(13.1,11.89 \%)$ for two seasons respectively. The same results were found in fruits held at room temperature for marketing.

These data are in harmony with those obtained by Abeer, (2011) who found that the lowest weight loss was attained by polyethylene packaging during cold storage for peach and apricot fruits. Also, Lim et al., (2011) illustrated that Sweet cherries coated with gelatin had lower levels of water loss over the storage period as compared to other treatments. These results may be due to that polyethylene packaging and some coating materials can offer a possibility to extend storage and shelf life of fruits produces by providing a semi-permeable layer to gases and water vapor Perez et al., (2004).

\section{Fruit color:}

It was evident from tables (2, 3 and 5 ) that (a) value (red color) increased significantly and gradually in all treatments and control fruits till the end of storage period during the two studied seasons. The change in (b) value (yellow color) was not obvious during storage period at cold storage and room temperature, this means that red pigments in apricot fruits are responsible for color development to orange during ripening stage.

Concerning the effect of postharvest treatments, control fruits had the highest (a) value compared with other treatments at cold storage and room temperature 
during the two seasons of the study. Fruits packed in polyethylene bags had the lowest values of this parameter followed by fruits treated with coat(2) and coat(1). This may be due that these treatments delay fruit ripening. These results are in agreement with El-Etreby et al., (2009) on Golden Japanese and Santa Rosa plum and also, El-Hadidy, (2008) on Flame Seedless grape.

Table 1. Effect of different methods of modified atmosphere on apricot fruit moisture loss (\%) during cold storage for two seasons (2010 and 2011)

\begin{tabular}{|c|c|c|c|c|c|}
\hline \multicolumn{6}{|c|}{2010 , season } \\
\hline & \multicolumn{4}{|c|}{ Storage period (Week) } & \multirow[b]{2}{*}{ Means $(T)$} \\
\hline Treatment $(\mathrm{T})$ & 1 & 2 & 3 & 4 & \\
\hline Poly. Bag & 0.09 & 0.13 & 0.31 & 0.52 & 0.26 \\
\hline Coat (1) & 5.89 & 11.23 & 15.31 & 19.98 & 13.10 \\
\hline Coat (2) & 3.80 & 8.38 & 13.54 & 17.79 & 10.88 \\
\hline Control & 5.65 & 12.33 & 18.95 & 26.87 & 15.95 \\
\hline Means (D) & 3.86 & 8.02 & 12.03 & 16.29 & \\
\hline
\end{tabular}

L.S.D. at $0.05(T)=$

L.S.D. at $0.05(D)=$

L.S.D. at $0.05(T X D)=$ 4.75

\begin{tabular}{|c|c|c|c|c|c|}
\hline \multicolumn{6}{|c|}{ 2011, season } \\
\hline \multirow[b]{2}{*}{ Treatment ( $\mathrm{T}$} & \multicolumn{4}{|c|}{ Storage period (Week) } & \multirow[b]{2}{*}{ Means $(T)$} \\
\hline & 1 & 2 & 3 & 4 & \\
\hline Poly. Bag & 0.11 & 0.15 & 0.43 & 0.44 & 0.28 \\
\hline Coat (1) & 7.59 & 9.73 & 12.50 & 17.73 & 11.89 \\
\hline Coat (2) & 5.34 & 9.73 & 13.54 & 17.73 & 11.59 \\
\hline Control & 4.71 & 10.83 & 19.10 & 26.37 & 15.25 \\
\hline Means (D) & 4.44 & 7.61 & 11.39 & 15.57 & \\
\hline
\end{tabular}

L.S.D. at $0.05(T)=$ 2.94

L.S.D. at $0.05(D)=$ 2.94

L.S.D. at $0.05(T X D)=$ 
Table 2. Effect of different methods of modified atmosphere on apricot fruit color (a value) during cold storage for two seasons (2010 and 2011)

\begin{tabular}{|l|c|c|c|c|c|c|}
\hline \multicolumn{7}{|c|}{ S010, season } \\
\hline \multirow{2}{*}{ Treatment (T) (D) } & \multicolumn{7}{|c|}{ Storage period (Week) } & \\
\cline { 2 - 7 } & 0 & 1 & 2 & 3 & 4 & Means (T) \\
\hline Poly. Bag & 6.80 & 7.20 & 9.60 & 8.20 & 9.80 & 8.32 \\
\hline Coat (1) & 9.50 & 9.90 & 12.70 & 11.20 & 12.50 & 11.16 \\
\hline Coat (2) & 8.90 & 8.20 & 11.30 & 12.30 & 12.60 & 10.66 \\
\hline Control & 8.80 & 12.20 & 13.60 & 12.80 & 13.00 & 12.08 \\
\hline & 8.50 & 9.38 & 11.80 & 11.13 & 11.98 & \\
\hline
\end{tabular}

L.S.D. at $0.05(T)=\quad 0.64$

$\begin{array}{ll}\text { L.S.D. at } 0.05(D)= & 0.72\end{array}$

L.S.D. at $0.05(T X D)=\quad 1.44$

\begin{tabular}{|c|c|c|c|c|c|c|}
\hline \multicolumn{7}{|c|}{2011 , season } \\
\hline \multirow[t]{2}{*}{ Date (D) } & \multicolumn{5}{|c|}{ Storage period (Week) } & \multirow[b]{2}{*}{ Means $(T)$} \\
\hline & 0 & 1 & 2 & 3 & 4 & \\
\hline Poly. Bag & 8.50 & 9.60 & 10.60 & 10.30 & 10.60 & 9.92 \\
\hline Coat (1) & 7.80 & 10.20 & 10.90 & 13.90 & 11.70 & 10.90 \\
\hline Coat (2) & 7.80 & 10.40 & 11.30 & 12.30 & 12.50 & 10.86 \\
\hline Control & 7.70 & 12.00 & 12.00 & 11.30 & 12.20 & 11.04 \\
\hline Means (D) & 7.95 & 10.55 & 11.20 & 11.95 & 11.75 & \\
\hline
\end{tabular}

L.S.D. at $0.05(T)=$

0.78

L.S.D. at $0.05(D)=$

0.87

L.S.D. at $0.05(T X D)=$

1.74 
Table 3. Effect of different methods of modified atmosphere on apricot fruit color (b value) during cold storage for two seasons (2010 and 2011)

\begin{tabular}{|c|c|c|c|c|c|c|}
\hline \multicolumn{7}{|c|}{2010 , season } \\
\hline & \multicolumn{5}{|c|}{ Storage period (Week) } & \multirow[b]{2}{*}{ Means $(T)$} \\
\hline Treatment $(T)$ & 0 & 1 & 2 & 3 & 4 & \\
\hline Poly. Bag & 58.40 & 54.30 & 55.60 & 56.20 & 53.50 & 55.60 \\
\hline Coat (1) & 55.00 & 54.70 & 55.80 & 54.60 & 58.10 & 55.64 \\
\hline Coat (2) & 57.20 & 57.40 & 56.10 & 57.30 & 57.00 & 57.00 \\
\hline Control & 53.10 & 53.00 & 55.70 & 56.20 & 56.80 & 54.96 \\
\hline Means (D) & 55.93 & 54.85 & 55.80 & 56.08 & 56.35 & \\
\hline
\end{tabular}

L.S.D. at $0.05(T)=\quad 1.21$

L.S.D. at $0.05(D)=\quad 1.36$

L.S.D. at $0.05(T X D)=\quad 2.71$

\begin{tabular}{|c|c|c|c|c|c|c|}
\hline \multicolumn{7}{|c|}{ 2011, season } \\
\hline \multirow[b]{2}{*}{ Treatment $(T)$} & \multicolumn{5}{|c|}{ Storage period (Week) } & \multirow[b]{2}{*}{ Means $(T)$} \\
\hline & 0 & 1 & 2 & 3 & 4 & \\
\hline Poly. Bag & 54.20 & 42.60 & 50.30 & 48.00 & 47.00 & 48.42 \\
\hline Coat (1) & 54.20 & 52.90 & 56.30 & 55.70 & 59.70 & 55.76 \\
\hline Coat (2) & 57.20 & 52.80 & 55.60 & 52.20 & 53.00 & 54.16 \\
\hline Control & 47.20 & 51.80 & 51.00 & 48.00 & 44.00 & 48.40 \\
\hline Means (D) & 53.20 & 50.03 & 53.30 & 50.98 & 50.93 & \\
\hline
\end{tabular}

L.S.D. at $0.05(T)=$

1.74

L.S.D. at $0.05(D)=$

1.95

L.S.D. at $0.05(T X D)=$

3.90 


\section{Fruit firmness:}

Data presented in tables (4 and 5) indicate that fruit firmness decreased significantly in control and other treatments during storage period. On the average both fruits packed in polyethylene bags or coated with coat (1) recorded more firmness in comparison with control in the first season. This may be due to that polyethylene and gelatin film can reduce respiration rate and minimize fruit moisture loss. Similar results were obtained by Abeer, ( 2011) on peach and apricot fruits and lim et al., (2011) on sweet cherries.

\section{Respiration rate:}

Average respiration rate in the two seasons of the study as affected by storage temperatures and treatments are presented in figure (1). Respiration rate of the initial time at room temperature was $11.6 \mathrm{mg} \mathrm{Co} / \mathrm{kg} / \mathrm{hr}$. This rate decreased approximately 10 times during the cold storage for treatments and control fruits. The data illustrated that the lowest value was observed in fruits coated by coat (2) followed by coat (1) and polyethylene bags in comparison with control in both seasons. These values were $0.54,0.69,0.90$ and $1.99 \mathrm{Co}_{2} / \mathrm{kg} / \mathrm{hr}$ respectively.

At room temperature $\left(20-25^{\circ} \mathrm{C}\right)$, the respiration rate increased than initial rate to reach $14.1,17.4,17.6,17.6 \mathrm{Co}_{2} / \mathrm{kg} / \mathrm{hr}$ for coat (2), coat (1), polyethylene bags and control fruits respectively at the end of marketing period. The fruits coated with coat (2) had the lowest value $14.1 \mathrm{Co}_{2} / \mathrm{kg} / \mathrm{hr}$ in comparison with other treatments and control. Control fruits had the highest respiration rate in both seasons of cold storage and marketing. The respiration rate reflects the role of low temperature and postharvest treatments in reducing deterioration of fruits. High respiration at high temperature and control fruits caused faster losses of fruit quality deterioration. These data illustrated that cold temperature is very important to reduce respiration rate, fruit deterioration and extend fruit life. These results were close to those obtained by Olivas and Barbosa-Ca' novas, (2005) and Mashraky et al., (2009).

\section{Physiological disorders:}

Data presented in figure (2) present the average existence of physiological disorders in the two seasons of the study as affected by storage temperatures and treatments. Physiological disorders appeared on apricot fruits after the fourth week of cold storage and after the fourth day on fruits held at room temperature. Physiological disorders symptoms were namely shriveling and brown pitting. On the average seasons, the highest physiological disorders percentage was obtained by control fruits and the lowest percentage was found in fruits packed in polyethylene bags, the fruits coated with coat (1) and coat (2) were between them at cold storage or room temperature. The data recorded that physiological disorders at cold storage after four 
weeks were $5 \%, 11 \%, 25 \%$ and $60 \%$ for polyethylene bags, coat (1), coat (2) and control respectively. At room temperature, these values were $2 \%, 30 \%, 20 \%$ and $70 \%$ after four days. These data agree with Souty et al., (1969), Mitchell, (1992) and Oliveira, (2009).

Table 4. Effect of different methods of modified atmosphere on apricot fruit firmness (Ib/inch ${ }^{2}$ ) during cold storage for two seasons (2010 and 2011)

\begin{tabular}{|c|c|c|c|c|c|c|}
\hline \multicolumn{7}{|c|}{2010 , season } \\
\hline & \multicolumn{5}{|c|}{ Storage period (Week) } & \multirow[b]{2}{*}{ Means $(T)$} \\
\hline Treatment $(T)$ & 0 & 1 & 2 & 3 & 4 & \\
\hline Poly. Bag & 18.21 & 16.80 & 15.10 & 13.60 & 13.00 & 15.34 \\
\hline Coat (1) & 18.21 & 16.00 & 15.00 & 12.80 & 10.75 & 14.55 \\
\hline Coat (2) & 18.21 & 14.60 & 13.30 & 12.40 & 9.77 & 13.66 \\
\hline Control & 18.21 & 15.20 & 14.27 & 12.13 & 9.43 & 13.85 \\
\hline Means (D) & 18.21 & 15.65 & 14.42 & 12.73 & 10.74 & \\
\hline
\end{tabular}

L.S.D. at $0.05(T)=0.68$

L.S.D. at $0.05(D)=\quad 0.76$

L.S.D. at $0.05(T X D)=1.52$

\begin{tabular}{|c|c|c|c|c|c|c|}
\hline \multicolumn{7}{|c|}{ 2011, season } \\
\hline \multirow[b]{2}{*}{ Treatment $(T)$} & \multicolumn{5}{|c|}{ Storage period (Week) } & \multirow[b]{2}{*}{ Means $(T)$} \\
\hline & 0 & 1 & 2 & 3 & 4 & \\
\hline Poly. Bag & 17.33 & 16.50 & 15.50 & 14.00 & 14.00 & 15.47 \\
\hline Coat (1) & 17.33 & 15.50 & 13.40 & 14.00 & 10.30 & 14.11 \\
\hline Coat (2) & 17.33 & 14.70 & 13.30 & 12.50 & 10.50 & 13.67 \\
\hline Control & 17.33 & 15.30 & 14.50 & 13.20 & 10.50 & 14.17 \\
\hline Means (D) & 17.33 & 15.50 & 14.18 & 13.43 & 11.33 & \\
\hline
\end{tabular}

L.S.D. at $0.05(T)=$ 1.16

L.S.D. at $0.05(D)=$ 
Table 5. Effect of different methods of modified atmosphere on apricot fruit moisture loss (\%), firmness and fruit color during marketing period (4 days) at room $\left(25-30^{\circ} \mathrm{C}\right)$ during two seasons (2010 and 2011)

\begin{tabular}{|c|c|c|c|c|c|c|c|c|}
\hline \multirow{3}{*}{ Treatment } & \multicolumn{4}{|c|}{ 1st Season } & \multicolumn{4}{|c|}{ 2nd Season } \\
\hline & \multirow{2}{*}{$\begin{array}{c}\text { Fruit } \\
\text { moisture } \\
\text { loss (\%) }\end{array}$} & \multirow{2}{*}{$\begin{array}{c}\text { Fruit } \\
\text { firmness } \\
\left(\mathrm{Ib} / \text { inch }^{2}\right)\end{array}$} & \multicolumn{2}{|c|}{ Fruit color } & \multirow{2}{*}{$\begin{array}{c}\text { Fruit } \\
\text { moisture } \\
\text { loss (\%) }\end{array}$} & \multirow{2}{*}{$\begin{array}{c}\text { Fruit } \\
\text { firmness } \\
\left(\mathrm{Ib} / \text { inch }^{2}\right)\end{array}$} & \multicolumn{2}{|c|}{ Fruit color } \\
\hline & & & $\begin{array}{c}(\mathrm{a} \\
\text { value) }\end{array}$ & $\begin{array}{c}(\mathrm{b} \\
\text { value) }\end{array}$ & & & $\begin{array}{c}(\mathrm{a} \\
\text { value })\end{array}$ & $\begin{array}{c}\text { (b } \\
\text { value) }\end{array}$ \\
\hline Initial & 0.00 & 18.21 & 8.50 & 55.93 & 0.00 & 17.33 & 7.95 & 53.20 \\
\hline Poly. Bag & 0.13 & 10.04 & 7.13 & 50.60 & 0.21 & 12.04 & 8.10 & 53.20 \\
\hline Coat (1) & 18.64 & 9.01 & 14.40 & 58.10 & 16.53 & 8.02 & 16.10 & 57.10 \\
\hline Coat (2) & 17.01 & 10.02 & 7.70 & 48.50 & 19.82 & 8.04 & 8.17 & 45.50 \\
\hline Control & 19.83 & 5.04 & 17.00 & 53.00 & 19.24 & 7.01 & 20.50 & 52.30 \\
\hline $\begin{array}{c}\text { L.S.D. at } 0.05 \\
=\end{array}$ & 1.35 & 2.74 & 1.08 & 2.31 & 1.69 & 2.97 & 1.17 & 2.07 \\
\hline
\end{tabular}
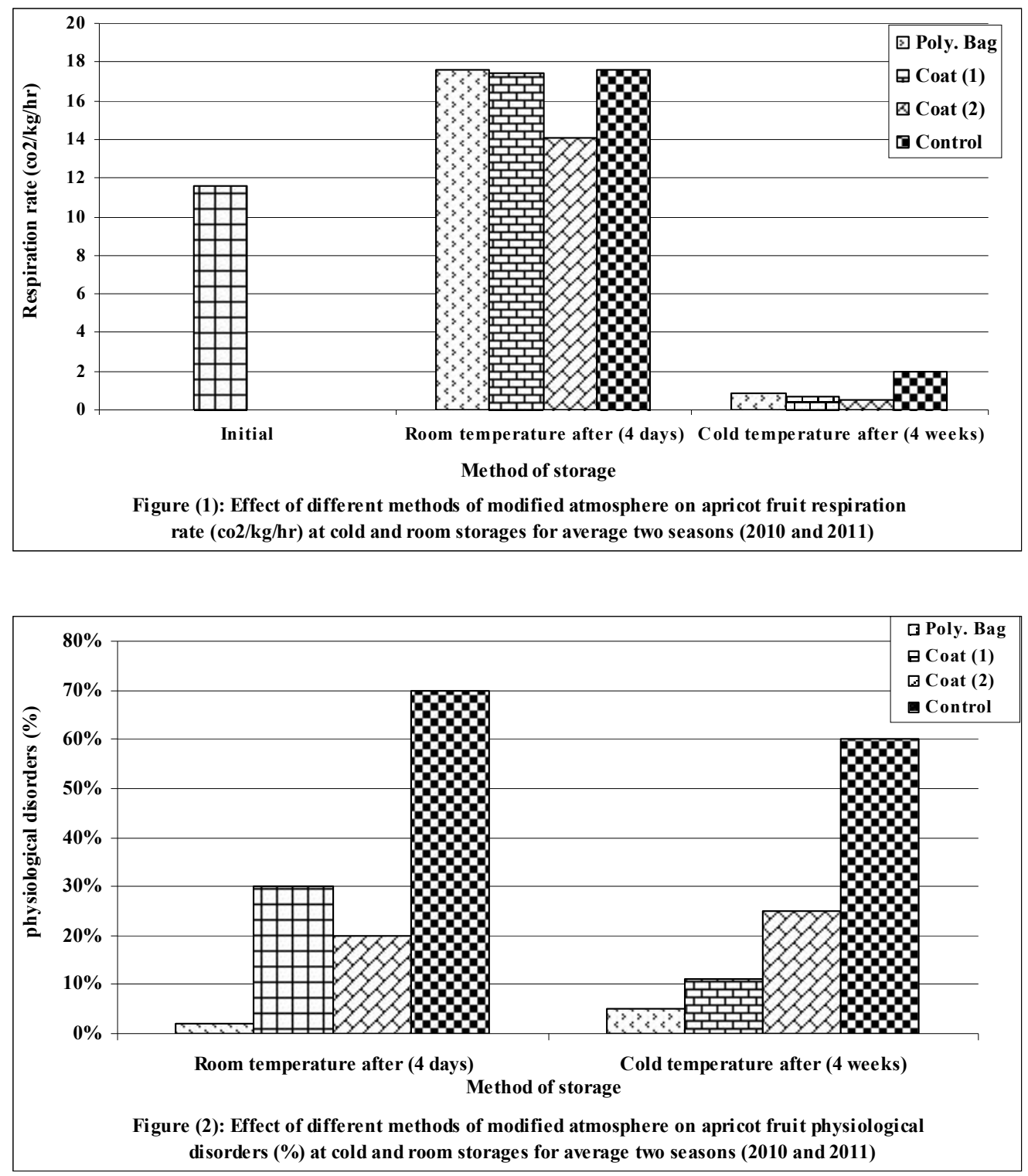


\section{Total soluble solids, total acidity and TSS/acid ratio:}

The results in tables $(6,7,8$ and 9) indicated that there was gradually and significantly increase in T.S.S. and decrease in acidity percentage during storage in all treatments and control in both seasons. Concerning the differences among treatments on total soluble solids, they were slight.

Regarding the effect of treatments on total acidity, control fruits had the least percentage in comparison with other treatments in both seasons of study. The increase in T.S.S. and decrease in acidity led to increase T.S.S./acid ratio by increasing storage period in all treatments and control fruits.

At the end of storage T.S.S./acid ratio was highest in control fruit. This is means that control fruits more ripening than other treatments. These results are in line with Mashraky et al., (2009) on apricot fruits and Fekry et al., (2008) on peach fruits. Infant et al., (2006) found that during apricot fruit storage, organic acids are the most easily oxidisable substrate available for respiration, so it is to be expected that their content declines postharvest.

In conclusion, it could be said the packaging remarkably increased storage life of El-Amar apricot fruits compare with other treatments and control. Storage life of fruits packed in polyethylene bags was three weeks at $0^{\circ} \mathrm{C}$ and $85-90 \%$ relative humidity. The extension of storage life was due to the reduction of losses in moisture content and respiration rate and thus maintaining the fruit quality of apricots. Respiration rate production was likewise retarded with low temperature storage and thus delaying senescence. In addition, low temperature storage reduced the losses in acidity contents of apricots. 
Table 6. Effect of different methods of modified atmosphere on apricot fruit T.S.S.

(\%) during cold storage for two seasons (2010 and 2011)

\begin{tabular}{|c|c|c|c|c|c|c|}
\hline \multicolumn{7}{|c|}{2010 , season } \\
\hline & \multicolumn{5}{|c|}{ Storage period (Week) } & \multirow[b]{2}{*}{ Means $(T)$} \\
\hline Treatment $(T)$ & 0 & 1 & 2 & 3 & 4 & \\
\hline Poly. Bag & 13.50 & 15.70 & 16.70 & 15.80 & 16.20 & 15.58 \\
\hline Coat (1) & 13.50 & 15.80 & 15.80 & 16.00 & 16.20 & 15.46 \\
\hline Coat (2) & 13.50 & 15.60 & 15.60 & 15.60 & 16.00 & 15.26 \\
\hline Control & 13.50 & 15.80 & 15.60 & 15.70 & 15.80 & 15.28 \\
\hline Means (D) & 13.50 & 15.73 & 15.93 & 15.78 & 16.05 & \\
\hline
\end{tabular}

$\begin{array}{ll}\text { L.S.D. at } 0.05(T)= & 0.24 \\ \text { L.S.D. at } 0.05(D)= & 0.27 \\ \text { L.S.D. at } 0.05(T X D)= & 0.53\end{array}$

\begin{tabular}{|c|c|c|c|c|c|c|}
\hline \multicolumn{7}{|c|}{2011 , season } \\
\hline \multirow[b]{2}{*}{ Treatment $(T)$} & \multicolumn{5}{|c|}{ Storage period (Week) } & \multirow[b]{2}{*}{ Means $(T)$} \\
\hline & 0 & 1 & 2 & 3 & 4 & \\
\hline Poly. Bag & 14.20 & 15.70 & 15.50 & 16.50 & 16.50 & 15.68 \\
\hline Coat (1) & 14.20 & 15.70 & 15.50 & 15.70 & 16.50 & 15.52 \\
\hline Coat (2) & 14.20 & 16.00 & 15.80 & 15.50 & 16.00 & 15.50 \\
\hline Control & 14.20 & 15.50 & 15.50 & 15.50 & 15.70 & 15.28 \\
\hline Means (D) & 14.20 & 15.73 & 15.58 & 15.80 & 16.18 & \\
\hline
\end{tabular}

L.S.D. at $0.05(T)=\quad 0.29$

L.S.D. at $0.05(D)=\quad 0.33$

L.S.D. at $0.05(T X D)=\quad 0.65$ 
Table 7. Effect of different methods of modified atmosphere on apricot fruit acidity (\%) during cold storage for two seasons (2010 and 2011)

\begin{tabular}{|c|c|c|c|c|c|c|}
\hline \multicolumn{7}{|c|}{2010 , season } \\
\hline \multirow[b]{2}{*}{ Treatme } & \multicolumn{5}{|c|}{ Storage period (Week) } & \multirow[b]{2}{*}{ Means $(\mathrm{T})$} \\
\hline & 0 & 1 & 2 & 3 & 4 & \\
\hline Poly. Bag & 2.30 & 1.00 & 0.81 & 0.73 & 0.56 & 1.08 \\
\hline Coat (1) & 2.30 & 0.90 & 0.75 & 0.68 & 0.65 & 1.06 \\
\hline Coat (2) & 2.30 & 0.90 & 0.74 & 0.67 & 0.67 & 1.06 \\
\hline Control & 2.30 & 0.85 & 0.70 & 0.66 & 0.60 & 1.02 \\
\hline Means (D) & 2.30 & 0.91 & 0.75 & 0.69 & 0.62 & \\
\hline
\end{tabular}

L.S.D. at $0.05(T)=\quad 0.04$

L.S.D. at $0.05(D)=\quad 0.05$

L.S.D. at $0.05(T X D)=\quad 0.09$

\begin{tabular}{|c|c|c|c|c|c|c|}
\hline \multicolumn{7}{|c|}{2011 , season } \\
\hline \multirow{2}{*}{ Date (D) } & \multicolumn{5}{|c|}{ Storage period (Week) } & \multirow[b]{2}{*}{ Means $(T)$} \\
\hline & 0 & 1 & 2 & 3 & 4 & \\
\hline Poly. Bag & 2.40 & 1.00 & 0.83 & 0.73 & 0.67 & 1.13 \\
\hline Coat (1) & 2.40 & 0.87 & 0.80 & 0.67 & 0.67 & 1.08 \\
\hline Coat (2) & 2.40 & 0.93 & 0.77 & 0.67 & 0.67 & 1.09 \\
\hline Control & 2.40 & 0.90 & 0.73 & 0.63 & 0.63 & 1.06 \\
\hline Means (D) & 2.40 & 0.93 & 0.78 & 0.68 & 0.66 & \\
\hline
\end{tabular}

L.S.D. at $0.05(T)=$ 0.03

L.S.D. at $0.05(D)=$

0.04

L.S.D. at $0.05(T X D)=$

0.07 
Table 8. Effect of different methods of modified atmosphere on apricot fruit T.S.S./acid ratio during cold storage for two seasons (2010 and 2011)

\begin{tabular}{|c|c|c|c|c|c|c|}
\hline \multicolumn{7}{|c|}{2010 , season } \\
\hline \multirow{2}{*}{ Treatment $(\mathrm{T})$} & \multicolumn{5}{|c|}{ Storage period (Week) } & \\
\hline & 0 & 1 & 2 & 3 & 4 & Means $(T)$ \\
\hline Poly. Bag & 5.87 & 15.70 & 20.62 & 21.64 & 28.93 & 18.55 \\
\hline Coat (1) & 5.87 & 17.56 & 21.07 & 23.53 & 24.92 & 18.59 \\
\hline Coat (2) & 5.87 & 17.33 & 21.08 & 23.28 & 23.88 & 18.29 \\
\hline Control & 5.87 & 18.59 & 22.29 & 23.79 & 26.33 & 19.37 \\
\hline Means (D) & 5.87 & 17.29 & 21.26 & 23.06 & 26.02 & \\
\hline
\end{tabular}

L.S.D. at $0.05(\mathrm{~T})=\quad 0.40$

L.S.D. at $0.05(D)=\quad 0.45$

$\begin{array}{ll}\text { L.S.D. at } 0.05(T X D)= & 0.89\end{array}$

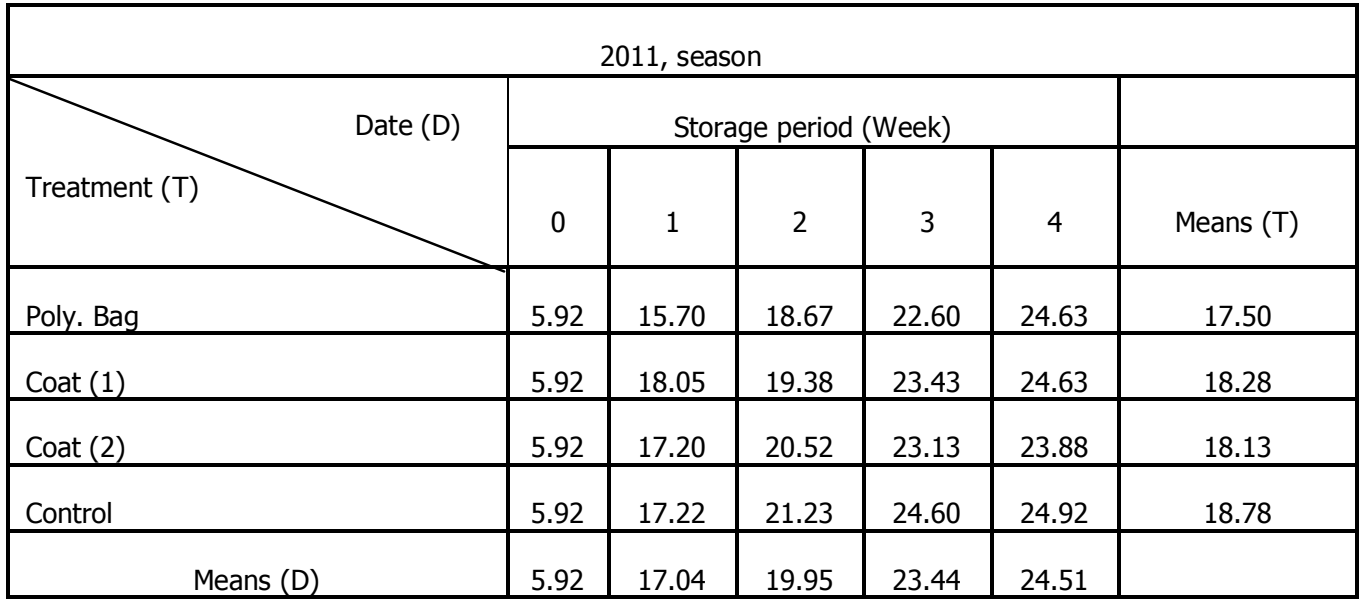

L.S.D. at $0.05(T)=$

0.46

L.S.D. at $0.05(D)=$

0.52

L.S.D. at $0.05(T X D)=$

1.03 
Table 9. Effect of different methods of modified atmosphere on apricot fruit TSS(\%), acidity(\%) and TSS/acid ratio during marketing period (4 days) at room $\left(25-30^{\circ} \mathrm{C}\right)$ during two seasons (2010 and 2011)

\begin{tabular}{|l|c|c|c|c|c|c|}
\hline \multirow{2}{*}{ Treatment } & \multicolumn{3}{|c|}{ 1st Season } & \multicolumn{3}{c|}{ 2nd Season } \\
\cline { 2 - 7 } & TSS (\%) & $\begin{array}{c}\text { Acidity } \\
(\%)\end{array}$ & $\begin{array}{c}\text { TSS/acid } \\
\text { ratio }\end{array}$ & TSS (\%) & $\begin{array}{c}\text { Acidity } \\
(\%)\end{array}$ & $\begin{array}{c}\text { TSS/acid } \\
\text { ratio }\end{array}$ \\
\hline Initial & 13.50 & 2.30 & 5.87 & 14.20 & 2.40 & 5.92 \\
\hline Poly. Bag & 13.80 & 2.00 & 6.90 & 14.00 & 2.00 & 7.00 \\
\hline Coat (1) & 15.30 & 1.90 & 8.05 & 14.20 & 1.80 & 7.89 \\
\hline Coat (2) & 15.10 & 1.70 & 8.88 & 13.10 & 1.80 & 7.28 \\
\hline Control & 13.80 & 1.70 & 8.12 & 14.10 & 1.70 & 8.29 \\
\hline L.S.D. at $0.05=$ & 0.13 & 0.03 & 1.27 & 0.17 & 0.02 & 1.43 \\
\hline
\end{tabular}

\section{REFERENCES}

1. A.O.A.C. 1990. Association of Official Agricultural Chemists Official Methods of Analysis $11^{\text {th }}$ Ed. published by the A.O.A.C., Washington, 4D. C. N. S. A. pp 440510.

2. Abeer, A.T.M. 2011. Performance of peach and apricot fruits at cold storage and shelf life as affected by modified atmosphere packaging. American - Eurasian J. Agric \& Enviro. Sci., (10) (S): 718-727.

3. Artés, F. 2002. Tratamientos térmicos y gaseosos post-recolección papa preserver la calidaf del albaricoque fresco. S.P. In: Tercer Congreso Iberoamericano Tecnologia Postharvest Agroexportaciones, Santiago, Cile, Dic. 3-6

4. Cross, R.A. 1966. Analysis of major constituents of pel gass by gas chromatography. Nature, 211, 409.

5. El-Etreby, S.M.A., M.K. Hemet, A.A.W. Waffa and E. Samia. 2009. Effect of some postharvest treatments and storage temperatures on fruit quality of two plum cultivars. Egypt J. of Appl. Sci., 24(4A): 225-240.

6. El-Hadidy, G.A.M. 2008. Studies on Flame Seedless grape and its storability in Egypt ans South Africa. Ph.D. Thesis, Institute of African, Cairo university, Egypt.

7. Fekry, O.M., G.R. Stino, S.M. Eloraby and N.R. Sherbini. 2008. Effect of some treatments on improving the fruit quality of Florida prince peaches. Egypt J. of Appl. Sci., 23(6B): 721-734.

8. Infante, R., Kraemer, F., Luchsinger, L., Weneses, C. and Aros, D. 2006. Seasonal postharvest quality evolution in apricot (Prunus armeniaca L.). Acta Horticulturae Vol 717, September page 321-325. 
9. Lim, R., Stathopoulos, C.E. and Golding, J.B. 2011. Effect of edible coatings on some quality characteristics of sweet cherries. International Food Research Journal 18(4): 1237-1241.

10. Magnes, J. R. and C.F. Taylor. 1925. An improved type of pressure for the determination of fruit maturity. U.S. Dept. Agric. PP. 350 - 358.

11. Manolopoulou, H. and Mallidis, C. 1999. Storage and processing of apricots. Acta Hort. 488: 567-576.

12. MC-Giuire, R.G. 1992. Reporting of objective colour measurements. HortScience 27 (12): 23-25.

13. Mitchell, F.G. 1992. Cooling horticultural commodities 1. The need for cooling. In: Kader, A. (Eds). Postharvest Technology of Horticultural Crops, p.53-56. Division of Agriculture and Natural Resources, University of California, Danis.

14. Mshraky, A.M., Hassan, G.F.A. and El-Tobgy, K.M.K. (2009): Some safe methods on keeping quality of apricot and its effect on respiration rate during cold storage. Annals of Agric. Sci., Moshtohor, Vol. 47(2): 203-211.

15. Olivas, G.I. and Barbosa-Canovas, G.V. 2005. Edible coatings for fresh-cut fruits. Crit.Rev. Food Sci.Nutr.,45:657-670.

16. Perez-Gago, M.B., Navarro Mall and M.A. del Rio. 2004. Effect of hydroxypropyl methylcellulose-beeswax edible composite coatings on 'Angeleno' plum quality during storage. $5^{\text {th }}$ international postharvest symposium. Verona, Italy 6-11 June. Volume of Abst. P:50. Scald and core breakdown and reduce Fungal decay in Bartlett pears.

17. Rodriguez-Aguilera, R.,and Oliveira, J.C. 2009. Review of design engineering methods an applications of active and modified atmosphere packaging systems. Food Eng.Rev.1:66-83.

18. Sharoba, A.M., Bahlol, H.E.M. and El-Desouky, A. I. 2007. Establishing a schedule to determine the optimal thermal process time for canned fruit products. Annals of Agric. Sc., Moshtohor, Vol. 45(1): 125-145.

19. Snedecor, G.W. and Cochran. W.G. 1990. Statistical Methods. 7th ed, The Iowa State Univ. Press . Ames., Iowa, U.S.A. , pp. 593.

20. Zarrin Bal, M., Eskandari, S., Soleymani, J. and Tabatabaei, M. 2009. Determining the suitable harvest time and packing method on fruit quality and cold storage duration of four apricot cultivars. International Information System for the Agricultural Science and Technology. 1-12. 


\section{تأثير طرق مختلفة من الجو المعدّل للحفاظ علي جودة ثمار المشمش صنف "العمار" خلال التسويق والتخزين المبرد} سامية العر ابى ، أمل مصطفى حسن ، علا محمد فكرى قسم بحوث تداول الفاكهة - معهد بحوث البساتين - مركز البحوث الزراعية بالجبزة - مصر

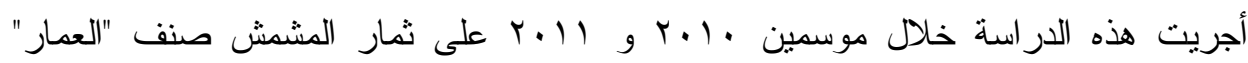
لأثجار مزروعة بمحافظة القليوبية لمقارنة تأثثر بعض طرق الجو المعدل لحفظ جودة ثمار

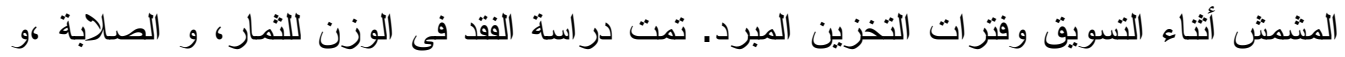

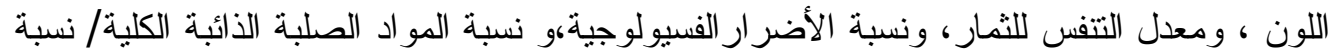

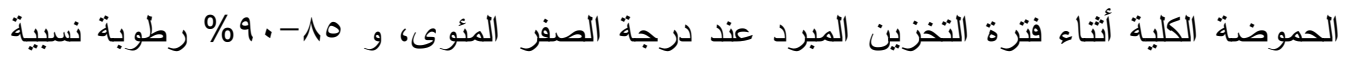

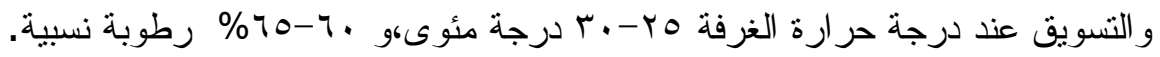

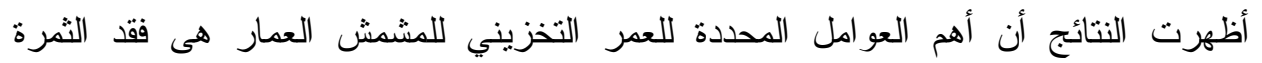
للرطوبة ، و الأضرار الفسيولوجية (النقر البنى و الكرمشة ) لذلك كان العمر التخزينى للثمار المعبأة

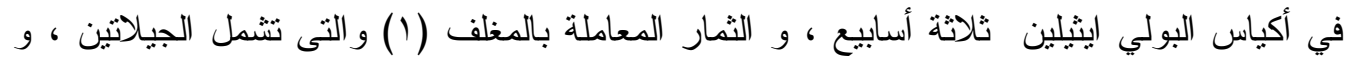

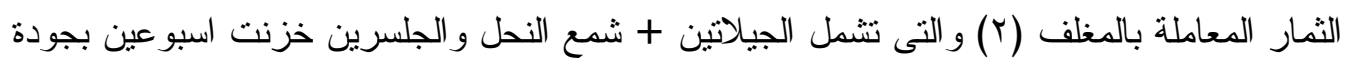

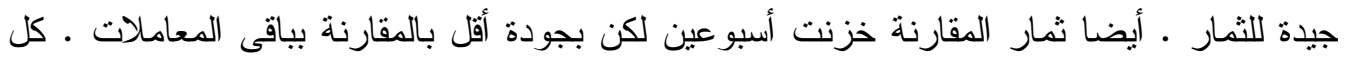

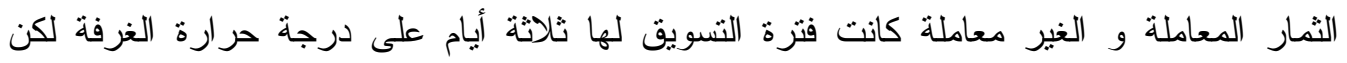

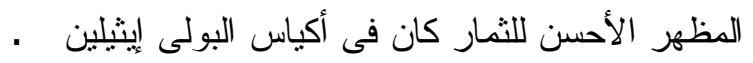

